\title{
PENGARUH PEMBERIAN EKSTRAK ETANOL UMBI BAWANG DAYAK (Eleutherine palmifolia (L.) Merr.) SECARA ORAL PADA MENCIT BALB/c TERHADAP PENCEGAHAN PENURUNAN DIAMETER GERMINAL CENTER PADA KELENJAR GETAH BENING SERTA KADAR IgG SERUM
}

\author{
Austin Bertilova Carmelita \\ Program Studi S2 Imunologi, Sekolah Pascasarjana Universitas Airlangga Surabaya \\ JL. Airlangga No. 4-6 Surabaya (60286) Telp. 031-5041566, Fax. (031) 5029856 \\ Email: austin.bertilova@yahoo.com
}

\begin{abstract}
ABSTRAK
Salah satu tanaman yang memiliki kandungan imunostimulator yaitu bawang dayak (Eleutherine palmifolia (L.) Merr.). Ekstrak etanol umbi bawang dayak (EEUBD) memiliki kandungan fitokimia yang bersifat sebagai antioksidan antara lain triterpenoid, flavonoid, fenolik, alkaloid dan tanin. Flavonol berpotensi sebagai imunostimulan meningkatkan produksi IL-2 yang terlibat dalam aktivasi dan proliferasi sel T. Flavonoid dapat menginduksi Th1 untuk menghasilkan IFN- $\gamma$, IFN- $\gamma$ berperan untuk menginduksi sel limfosit B memproduksi imunoglobulin. Untuk mengetahui potensi pengaruh pemberian ekstrak etanol umbi bawang dayak dalam pencegahan penurunan diameter germinal center pada kelenjar getah bening serta pencegahan penurunan kadar Ig $\mathrm{G}$ serum pada mencit yang diinduksi metilprednisolon oral dilakukan penelitian dengan desain eksperimental. Pada penelitian ini mencit dikelompokkan menjadi lima kelompok yaitu kelompok I (K1) merupakan perlakuan kontrol hanya diberi $\mathrm{CMC} \mathrm{Na}^{+} 0,5 \%$. Kelompok II (K2) merupakan model imunosupresi yaitu kelompok perlakuan yang diinduksi metilprednisolon $0,08 \mathrm{mg} / 30$ grBB mencit/ hari terlarut dalam 0,2 ml aquades. Kelompok III (K3) dengan perlakuan metilprednisolon ditambah EEUBD dengan dosis $50 \mathrm{mg} / \mathrm{kgBB}$. Kelompok IV (K4) dengan perlakuan metilprednisolon ditambah EEUBD dengan dosis $100 \mathrm{mg} / \mathrm{kgBB}$ dan kelompok $\mathrm{V}$ (K5) dengan perlakuan metilprednisolon ditambah EEUBD dengan dosis $200 \mathrm{mg} / \mathrm{kgBB}$, diberikan sekali sehari selama 14 hari bersamaan pemberian induksi metilprednisolon pada sore hari secara per-oral (sonde intragastrik). Kemudian diamati peningkatan diameter germinal center dan kadar Ig G serum. Data hasil penelitian antar kelompok dianalisis dengan menggunakan uji korelasi bivariat koefisien pearson. Hasil penelitian menunjukkan bahwa EEUBD terbukti sebagai imunostimulator terhadap peningkatan diameter germinal center pada dosis $100 \mathrm{mg} / \mathrm{kgBB}$ dan peningkatan kadar Ig G serum pada dosis $200 \mathrm{mg} / \mathrm{kgBB}$.
\end{abstract}

Kata-kata kunci : bawang dayak (Eleutherine palmifolia (L.) Merr.), germinal center, imunoglobulin $\mathrm{G}(\mathrm{Ig} \mathrm{G})$ 


\section{ABSTRACT}

One of the plants that contain immunostimulatory is Dayak's onion (Eleutherine palmifolia (L.) Merr.). The ethanol extract of Dayak's onion contains phytochemicals that act as antioxidants include triterpenoids, flavonoids, phenolics, alkaloids and tannins. Flavonols potential as an immunostimulant increase the production of IL-2 is involved in the activation and proliferation of $T$ cells can induce Th1 flavonoids to produce IFN- $\gamma$, IFN- $\gamma$ role is to induce B lymphocyte cells producing immunoglobulins. To determine the potential effect of ethanol extract of Dayak's onion to prevent deterioration diameter germinal center of the lymph nodes as well as the prevention of decreased levels of serum Ig $G$ in mice induced oral methylprednisolone research with experimental design. In this study, mice were divided into five groups: group $I(K 1)$ is a control treatment was only given $\mathrm{CMC} \mathrm{Na}^{+}$0.5\%. Group II (K2) is a model of immunosuppression is induced methylprednisolone treatment group $0.08 \mathrm{mg} / 30 \mathrm{grBW}$ mice / day dissolved by $0.2 \mathrm{ml}$ of distilled water. Group III (K3) by treatment with methylprednisolone combined with ethanol extract of Dayak's onion a dose of 50 $\mathrm{mg} / \mathrm{kgBW}$. Group IV (K4) by treatment with methylprednisolone combined with ethanol extract of Dayak's onion a dose and group $V(K 5)$ by treatment with methylprednisolone combined with ethanol extract of Dayak's onion with a dose of $200 \mathrm{mg} / \mathrm{kgBW}$, administered once daily for 14 days concurrent administration of methylprednisolone orally (sonde intragastric) are induction in the afternoon. Then the observed increase in the diameter of germinal center and G serum Ig levels. Research data between groups were analyzed using Pearson's correlation coefficient bivariate. The results showed that ethanol extract of Dayak's onion proved an immunostimulatory to the increased diameter of the germinal center at the dose of $100 \mathrm{mg} / \mathrm{kgBW}$ and elevated levels of serum Ig G at the dose of $200 \mathrm{mg} / \mathrm{kgBW}$.

Key words: Dayak's onion (Eleutherine palmifolia (L.) Merr.), germinal center, immunoglobulin G ( $\operatorname{Ig} G)$

\section{PENDAHULUAN}

Kemampuan tubuh untuk melindungi diri, agar terhindar dari suatu penyakit sangat tergantung pada sistem kekebalan tubuh atau sistem imun, baik yang bersifat innate immunity (ketahanan tubuh alami/bawaan) maupun adaptive immunity (ketahanan tubuh yang didapat). Jejas adalah semua tekanan baik pada tingkat molekuler atau seluler (Sudiana, 2014).

Masyarakat Kalimantan Tengah telah memanfaatkan tanaman sebagai obat secara turun temurun. Bawang dayak (Eleutherine palmifolia (L.) Merr.) adalah salah satu tanaman yang dipercaya memiliki khasiat menyembuhkan berbagai jenis penyakit. Sampai saat ini tanaman bawang dayak digunakan untuk terapi penyakit kanker usus, kanker payudara, diabetes melitus, hipertensi, menurunkan kolesterol, obat bisul, stroke, sakit perut sesudah melahirkan. (Galingging, 2009). Tanaman bawang dayak bisa dianggap sebagai obat dewa bagi penduduk Kalimantan Tengah.

Kortikosteroid merupakan obat yang sangat banyak dan luas dipakai dalam dunia kedokteran. Glukokortikoid digunakan luas pada banyak kelainan-kelainan non endokrin dengan variasi penggunaan yang besar baik dalam pemilihan obat maupun dosisnya antara lain penyakit-penyakit rheumatik/Collagen (SLE, Polyarteritis nodusa), penyakit ginjal (sindroma nefrotik, glomerulonephritis membranous), penyakit-penyakit allergi, 
asthma bronchiale, infeksi, penyakit-penyakit mata, penyakit-penyakit kulit, penyakitpenyakit gastrointestinal, penyakit kelainan hematologi dan onkologi, edema otak, shock, transplantasi organ dan stroke dan trauma spinal cord (Azis, 2006).

Begitu luasnya penggunaan kortikosteroid ini bahkan banyak yang digunakan tidak sesuai dengan indikasi maupun dosis dan lama pemberian, seperti pada penggunaan kortikosteroid sebagai obat untuk menambah nafsu makan dalam waktu yang lama dan berulang sehingga bisa memberikan efek yang tidak diinginkan (Azis, 2006). Salah satu efek samping steroid adalah dengan melemahkan sistem kekebalan tubuh. Jika sistem kekebalan tubuh dilemahkan, kerentanan tubuh terhadap infeksi virus maupun bakteri menjadi meningkat. Pada pasien yang mengkonsumsi steroid sering terjadi infeksi jamur pada mulut (thrush) atau vagina (RSCM Kirana, 2014; Sumarwoto T, 2004). Berdasarkan hal tersebut perlu dipikirkan terapi alternatif dari bahan alam yang memiliki efek memodulasi sistem imun, sehingga pasien yang mendapat terapi kortikosteroid tidak mengalami penurunan sistem imun.

Kemampuan bawang dayak menyembuhkan berbagai penyakit yang dipercaya masyarakat Kalimantan Tengah memberi harapan bahwa tanaman obat ini dapat digunakan sebagai bahan yang bersifat modulasi sistem imun. Namun, bagaimana pengaruh dari tanaman bawang dayak terhadap modulasi sistem imun masih belum dapat dijelaskan.

$\begin{array}{rrr} & \text { Imunomodulator adalah bahan (obat) } \\ \text { yang } & \text { dapat } & \text { mengembalikan }\end{array}$ ketidakseimbangan sistem imun (Chairul dan Praptiwi, 2008). Senyawa yang mempunyai bioaktifitas sebagai imunostimulan agen adalah golongan senyawa polisakarida, terpenoids, alkaloid dan poli-fenol (Wagner, 1985). Flavonol berpotensi sebagai imunostimulan karena mampu meningkatkan produksi IL-2 yang terlibat dalam aktivasi dan proliferasi sel T (Dewi et al, 2013). Flavonoid dapat menginduksi Th1 untuk menghasilkan IFN- $\gamma$, IFN- $\gamma$ berperan untuk menginduksi sel limfosit B memproduksi imunoglobulin (Annisa, 2014).
Sebuah penelitian yang dilakukan Febrinda dkk (2013) menunjukkan ekstrak etanol umbi bawang dayak memiliki kandungan fitokimia yang bersifat sebagai antioksidan antara lain triterpenoid, flavonoid, fenolik, alkaloid dan tanin. Senyawa flavonoid yang terdapat pada tanaman terbukti dapat menstimulasi sistem imun dengan meningkatkan aktivitas makrofag dan limfosit T (Zalisar, 2013). Peneliti yang lain juga membuktikan bahwa ekstrak etanol bawang dayak memiliki kemampuan sebagai imunomodulator dengan meningkatkan Ig M pada mencit (Annisa, 2014).

Flavonoid dapat menginduksi Th1 untuk menghasilkan IFN- $\gamma$, IFN- $\gamma$ berperan untuk menginduksi sel limfosit $\mathrm{B}$ yang berada di organ limfoid sekunder berproliferasi menjadi sel plasma. Sel plasma adalah fase akhir dari sel limfosit B yang memproduksi immunoglobulin, salah satunya immunoglobulin $\mathrm{G}$ ( $\mathrm{IgG}$ ). Proses proliferasi sel B menjadi sel plasma dapat ditunjukkan dengan adanya peningkatan diameter germinal center pada kelenjar getah bening.

Berdasarkan hal tersebut peneliti berupaya untuk melakukan penelitian pengaruh pemberian ekstrak etanol umbi bawang dayak (Eleutherine palmifolia (L.) Merr.) secara oral pada mencit BALB/c terhadap pencegahan penurunan jumlah sel plasma dan diameter germinal center pada kelenjar getah bening serta kadar IgG pada serum.

\section{METODE PENELITIAN}

\section{Instrumen Penelitian}

1. Alat pemeliharaan mencit : Kandang mencit dari kotak plastik, ram kawat, alas kandang, tempat makanan dan botol air.

2. Alat untuk pembedahan mencit : kotak kaca dan penutup kaca pembiusan, scalpel (pisau bedah), surgical scissor (gunting bedah) dan pinset.

3. Alat untuk melarutkan dan pemberian ekstrak etanol umbi bawang dayak : timbangan mikro Toledo, tabung falcon, alumunium foil, vortex mixer, sonde lambung, spuit $1 \mathrm{ml}$ terumo dan rak tabung reaksi.

4. Mikroskop.

5. ELISA Kit reader 


\section{Bahan Penelitian}

1. Hewan coba dengan kriteria jenis mencit (Mus musculus) : BALB/c berjenis kelamin : jantan, umur 12 minggu dengan berat badan 25 - 30 gram, kesehatan mencit dapat diamati dengan gerakan cukup lincah, tidak lesu, kulit bersih dan tanpa luka, mata terang dan tidak sayu.

2. Jenis makanan pellet CP 511 dan jenis minuman aquadestila.

3. Perawatan mencit pemberian makanan pellet, pemberian minum secara ad libitum $5 \mathrm{ml} / \mathrm{ekor} / 4$ hari,penggantian sekam untuk alas tidur 2 hari sekali, untuk sanitasi kandang dibersihkan setiap hari dengan suhu sesuai dengan suhu ruang, ventilasi dan sinar matahari yang cukup dan tidak lembab.

4. Pembuatan ekstrak etanol bawang dayak. Umbi bawang dayak dikupas kulit luarnya dicuci bersih dan diiris tipis-tipis, kemudian diangin-anginkan hingga kering. Selanjutnya irisan umbi bawang dayak tersebut dibuat serbuk. Ditimbang 500 gram serbuk umbi bawang dayak kering, ditambahkan $2 \mathrm{ml}$ etanol kemudian disimpan selama 24 jam ( serbuk bawang dayak dilarutkan dalam $2 \mathrm{ml}$ etanol $96 \%$ dengan metode maserasi yaitu bahan direndam etanol 1 x 24 jam hingga etanolnya menguap, lalu disaring untuk diambil fibrat nya). Besoknya ditampung kemudian dirotavator. Ada sisa sari ditambahkan 1,5 liter etanol, didiamkan 24 jam. Ampas bawang dayak dimaserasi kembali selama 1 x 24 jam kemudian diambil filtratnya. Besoknya diambil lagi, dirotavator kembali, sisanya diberi etanol 1,5 liter, hal ini dilakukan selama 3 hari berturut-turut. Pembagian filtrat dilakukan 3 kali kemudian semua filtrat dikumpulkan menjadi satu, lalu diuapkan dengan alat rotary evaporator buchi R-200 melalui penurunan tekanan pada suhu $40-45$ derajat celcius, sehingga diperoleh ekstrak kental bawang dayak. Selanjutnya dibuat sediaan ekstrak etanol umbi bawang dayak konsentrasi $50 \mathrm{mg} / \mathrm{kgBB}$ dengan cara diambil 0,1 ml EEUBD larutkan bersama $0,1 \mathrm{ml}$ larutan $\mathrm{CMC} \mathrm{Na}^{+} 0,5 \%$. Dibuat juga sediaan ekstrak etanol umbi bawang dayak konsentrasi $100 \mathrm{mg} / \mathrm{kgBB}$ dengan cara diambil 0,2 ml EEUBD larutkan bersama
$0,1 \mathrm{ml}$ larutan $\mathrm{CMC} \mathrm{Na}^{+} 0,5 \%$. Terakhir dibuat sediaan ekstrak etanol umbi bawang dayak konsentrasi $200 \mathrm{mg} / \mathrm{kgBB}$ dengan cara diambil 0,3 ml EEUBD larutkan bersama $0,1 \mathrm{ml}$ larutan $\mathrm{CMC} \mathrm{Na}^{+} 0,5 \%$.

5. Pembuatan larutan Metilprednisolon berdasarkan dosis oral $25 \mathrm{mg} / \mathrm{kgBB}$.

Pembuatan larutan induksi metilprednisolon berupa $0,08 \quad \mathrm{mg}$ metilprednisolon $/ 30 \mathrm{grBB}$ mencit/ hari dilarutkan bersama $0,2 \mathrm{ml}$ larutan CMC $\mathrm{Na}^{+} 0,5 \%$.

6. Ketamin ( Ketamine $\mathrm{HCl} / 2-(0-$ chlorophenil) - 2 (methylamino) cyclohexanone hydrochloride ) dengan dosis $0,025 \mathrm{mg} / 10$ grBB mencit berdasarkan dosis $10 \mathrm{mg} / \mathrm{kgBB}$.

7. Larutan $\mathrm{CMC} \mathrm{Na}^{+} 0,5 \%$

8. Formalin $10 \%$, etanol 70\%, 80\%, 99\%, xylol, Paraffin cair, kaset, cover slip, base mould, beker glass, gelas ukur, termometer, cutter, pinset panjang, tissue processor auto technicon", hot plate, cold plate, paraffin dispenser untuk membuat preparat.

9. Rotary microtome, disposable blad, kuas cat air kecil nomor 1, Tissue flotation bath, kaca obyek, diamond pencil, staining rack, hot plate, aquadestilata.

10.Bahan-bahan kimia untuk pewarnaan Haematoksilin Eosin (HE).

\section{Mouse Ig-G ELISA Kit}

Ekstrak yang diteliti berupa ekstrak etanol dari umbi Bawang Dayak. Jumlah mencit yang digunakan pada penelitian ini adalah 30 ekor dan dibagi secara acak menjadi 5 kelompok, masing-masing kelompok terdiri dari 6 ekor. Kelompok pertama kontrol negatif diberi $\mathrm{CMC} \mathrm{Na}$, kelompok kedua diberi Metilprednisolon, kelompok ketiga, keempat dan kelima diberi ekstrak etanol umbi bawang dayak berturut-turut dengan dosis 50, 100 dan $200 \mathrm{mg} / \mathrm{kgBB}$ bersama Metilprednisolon dengan dosis $0,08 \mathrm{mg} / 30$ grBB mencit/hari. Pemberian perlakuan dilakukan 1 kali sehari pada sore hari. Sebelum diberikan perlakuan, semua mencit dalam setiap kelompok pelakuan diaklimatisasi selama 1 minggu. Proses perlakuan berlangsung selama 14 hari dan pada pagi hari ke 15 dilakukan terminasi untuk pengambilan darah dari ekor mencit dan sampel KGB mencit. Pengamatan diameter 
germinal center dan kadar Ig $G$ serum dilakukan. Analisis statistik dengan uji korelasi bivariat koefisien pearson.

\section{HASIL DAN PEMBAHASAN}

Pada penelitian ini menggunakan sampel mencit strain BALB/C sebagai model imunosupresi dengan pemberian obat kortikosteroid (metilprednisolon). Penggunaan metilprednisolon pada penelitian ini dengan alasan pertimbangan obat tersebut banyak digunakan dan merupakan kortikosteroid oral yang paling sering digunakan dalam terapi berbagai penyakit dan juga digunakan sebagai supresi penyakit jangka panjang (PIO Nas, 2015, Dexa Medica, 2016).

Kelompok I (K1) merupakan kelompok normal (kontrol positif) tanpa perlakuan ekstrak etanol umbi bawang dayak (EEUBD) dan tanpa diinduksi metilprednisolon hanya diberi $\mathrm{CMC} \mathrm{Na}^{+} 0,5 \%$. Kelompok II (K2) merupakan kelompok model imunosupresi (kontrol negatif) yaitu kelompok perlakuan yang diinduksi kortikosteroid jenis metilprednisolon $0,08 \mathrm{mg} / 30 \mathrm{grBB}$ mencit/ hari terlarut $\mathrm{dlm} 0,2 \mathrm{ml}$ aquades tanpa perlakuan EEUBD. Sedangkan kelompok III-V (K3, K4 dan K5) dengan perlakuan EEUBD dengan dosis $0,25 \mathrm{ml} / 30 \mathrm{~g}$ berat badan mencit konsentrasi $50 \mathrm{mg} / \mathrm{kgBB}, 100 \mathrm{mg} / \mathrm{kgBB}$ dan $200 \mathrm{mg} / \mathrm{kgBB}$, diberikan sekali sehari selama 14 hari bersamaan pemberian induksi metilprednisolon pada sore hari secara per-oral (sonde intragastrik)

\section{Pengaruh Pemberian Ekstrak Etanol Umbi Bawang Dayak (EEUBD) Terhadap Pencegahan Penurunan Diameter Germinal Center}

Diameter germinal center pada KGB mencit $\mathrm{BALB} / \mathrm{C}$ yang diwarnai menggunakan Hematoksilin-Eosin (HE).
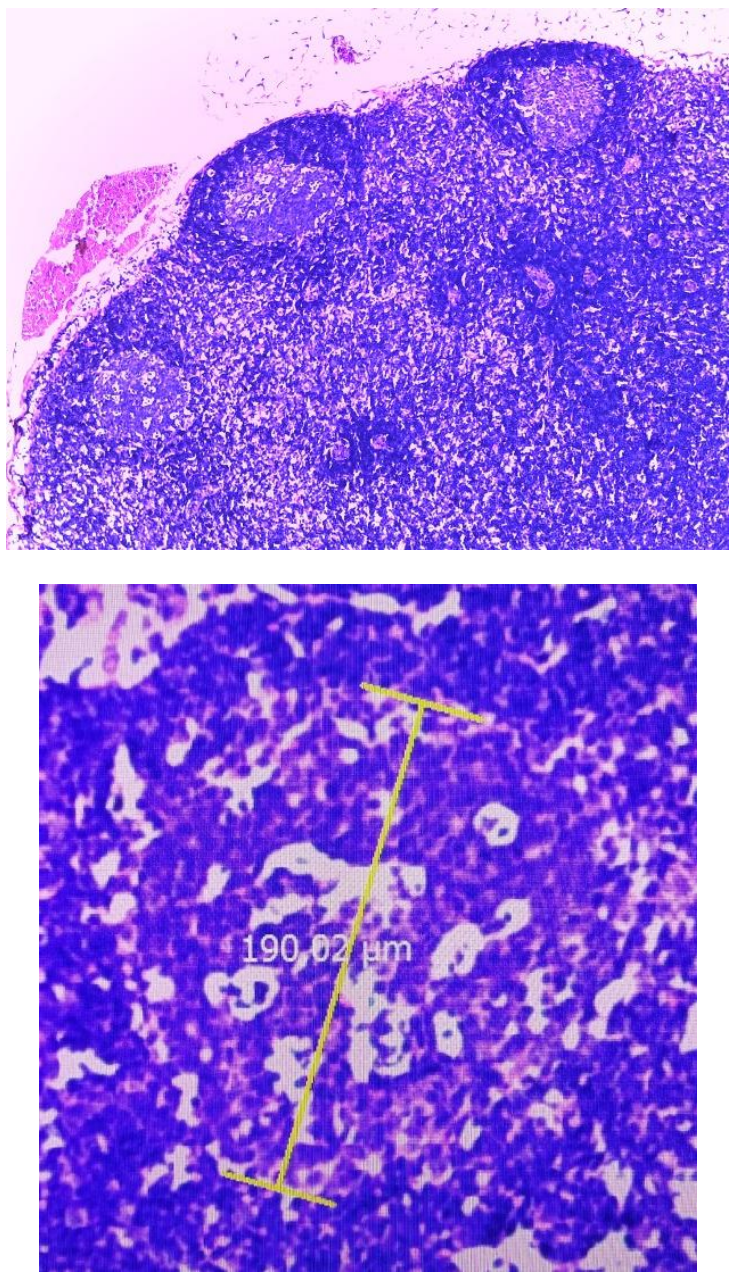

Gambar 1. Diameter germinal center.

Tabel 1. Diameter germinal center KGB mencit Balb/C antar kelompok perlakuan (satuan $\mu \mathrm{m}$ )

\begin{tabular}{|c|c|c|c|c|}
\hline Kelompok & $\begin{array}{c}\text { Rerat } \\
\text { a }\end{array}$ & SD & $\begin{array}{c}\text { Min } \\
\text { imu } \\
\text { m }\end{array}$ & $\begin{array}{c}\text { Ma } \\
\text { ksi } \\
\text { mu } \\
\text { m }\end{array}$ \\
\hline $\mathrm{CMC} \mathrm{Na}^{+}$ & 189,4 & 58,3 & $\begin{array}{c}120 \\
4\end{array}$ & $\begin{array}{c}280, \\
2\end{array}$ \\
\hline $\mathrm{MP}$ & 188,3 & 33,7 & $\begin{array}{c}155, \\
1\end{array}$ & $\begin{array}{c}249, \\
3\end{array}$ \\
\hline $\begin{array}{l}\mathrm{MP}+\text { EEUBD } 50 \\
\mathrm{mg} / \mathrm{KgBB}\end{array}$ & 209,0 & 45,0 & $\begin{array}{c}147, \\
7\end{array}$ & $\begin{array}{c}259, \\
2\end{array}$ \\
\hline $\begin{array}{l}\mathrm{MP}+\mathrm{EEUBD} 100 \\
\mathrm{mg} / \mathrm{KgBB}\end{array}$ & 214,6 & 25,6 & $\begin{array}{c}181 \\
4\end{array}$ & $\begin{array}{c}239, \\
2\end{array}$ \\
\hline $\begin{array}{l}\mathrm{MP}+\mathrm{EEUBD} 200 \\
\mathrm{mg} / \mathrm{KgBB}\end{array}$ & 207,1 & 29,2 & $\begin{array}{c}183, \\
0\end{array}$ & $\begin{array}{c}262 \\
7\end{array}$ \\
\hline
\end{tabular}

Keterangan :

MP : Metilprednisolon 


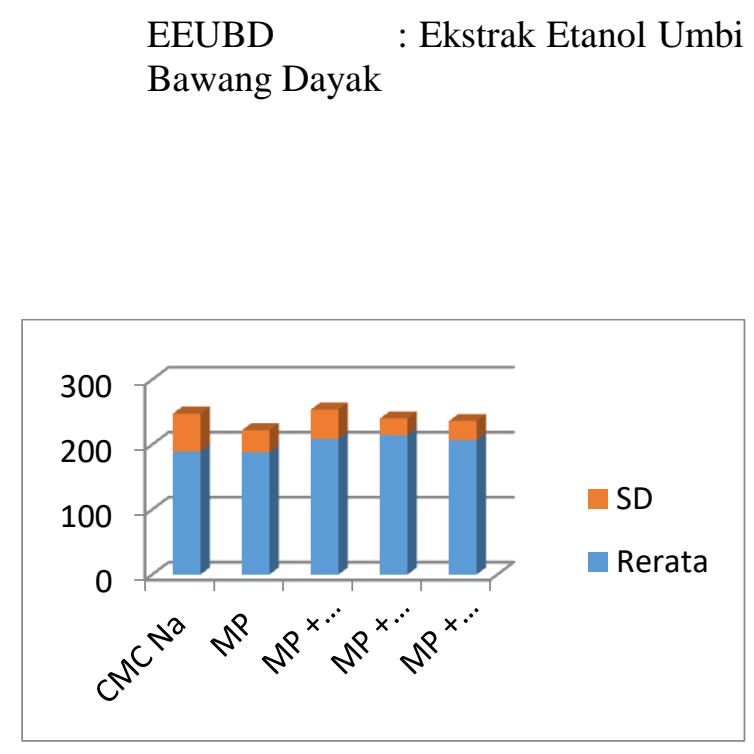

Gambar 2.

Rerata diameter germinal center pada setiap kelompok perlakuan

Tabel 2. Uji Korelasi Bivariat Koefisien Pearson rerata diameter germinal center

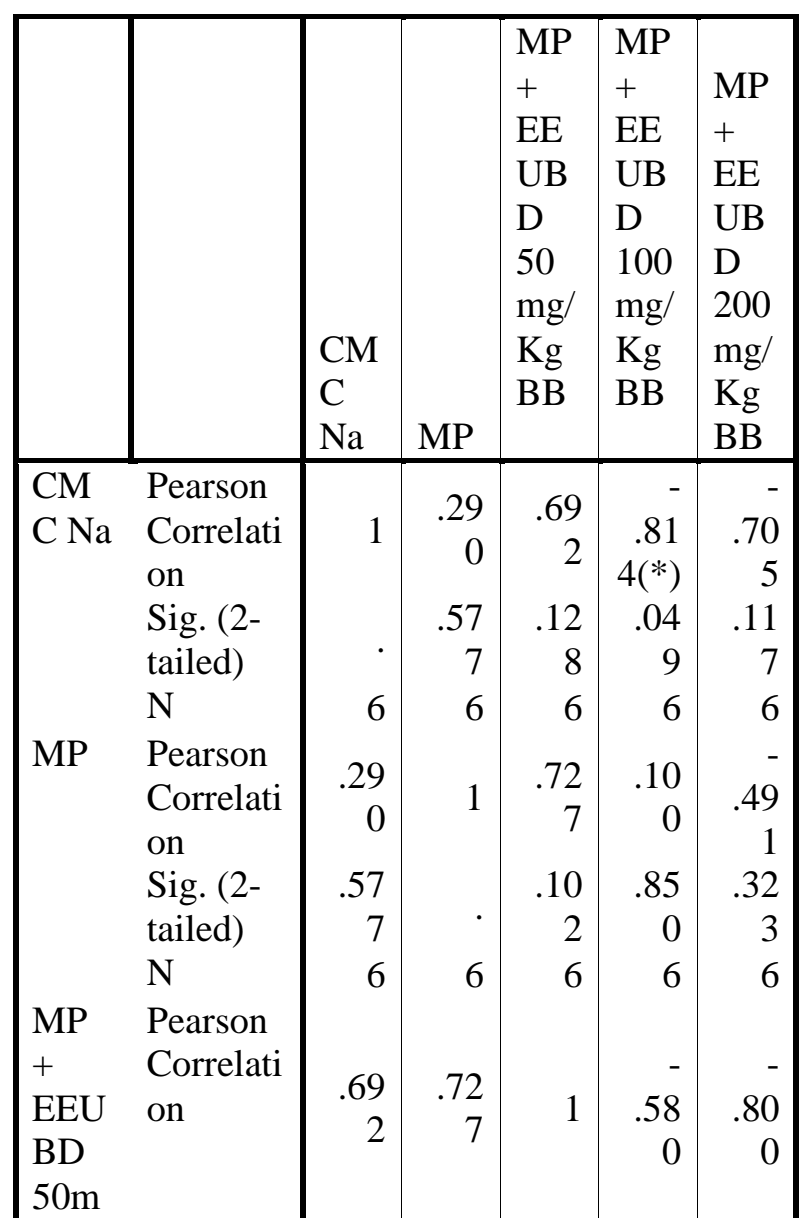

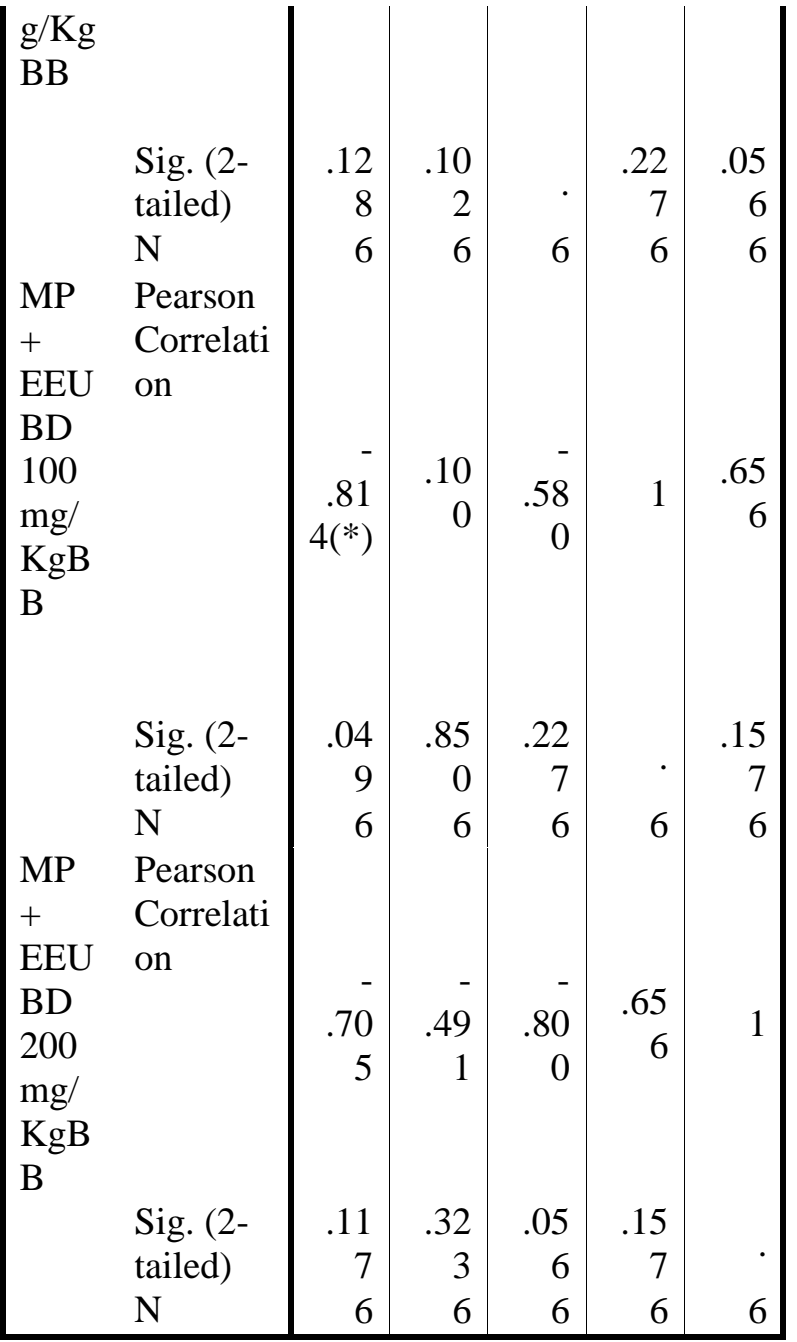

* Correlation is significant at the 0.05 level (2-tailed).

Berdasarkan Tabel 1 menunjukkan rerata diameter germinal center paling rendah pada kelompok K2 yang merupakan kelompok model imunosupresi. Selanjutnya diikuti dengan rerata diameter germinal center pada kelompok K1 yang merupakan kelompok kontrol (normal). Pada kelompok K3-K5 rerata diameter germinal center lebih besar dari K2 maupun K1.

Berdasarkan tabel 2. maka terlihat uji korelasi bivariat koefisien pearson antara kelompok perlakuan $\mathrm{CMC} \mathrm{Na}^{+}(\mathrm{K} 1)$ terhadap $\mathrm{K} 2$, K3, K4 dan K5. Jika dibandingkan diameter germinal center antara $\mathrm{K} 1$ dengan $\mathrm{K} 2$, K3 dan K5 didapatkan bahwa perbedaan rerata diameter germinal center berbeda tidak bermakna $(\mathrm{p}>0,05)$ dengan nilai $\mathrm{p}$ masingmasing $0,577,0,128$ dan 0,117. Sedangkan pada perbandingan rerata diameter germinal 
center antara K1 dengan K4 (kelompok perlakuan yang diberikan metilprednisolon dikombinasikan dengan EEUBD $100 \mathrm{mg} / \mathrm{KgBB}$ ) didapatkan hasil $\mathrm{p}<0,05$ yaitu $\mathrm{p}=0,049$.

Uji korelasi bivariat koefisien pearson antara kelompok perlakuan Metilprednisolon (K2) terhadap K1, K3, K4 dan K5. Rerata diameter germinal center pada $\mathrm{K} 2$ jika dibandingkan dengan masing-masing rerata diameter germinal center $\mathrm{K} 1, \mathrm{~K} 3, \mathrm{~K} 4$ dan K5 didapatkan semua hasil yang berbeda secara tidak bermakna karena semua nilai $\mathrm{p}>0,05$ yakni $\mathrm{p}=0,577, \quad \mathrm{p}=0,102, \quad \mathrm{p}=0,850 \quad$ dan $\mathrm{p}=0,323$.

Uji korelasi bivariat koefisien pearson antara kelompok perlakuan Metilprednisolon ditambah dengan EEUBD dosis $50 \mathrm{mg} / \mathrm{KgBB}$ (K3) terhadap K1, K2, K4 dan K5. Rerata diameter germinal center pada K3 jika dibandingkan dengan masing-masing rerata diameter germinal center K1, K2, K4 dan K5 didapatkan semua hasil yang berbeda secara tidak bermakna karena semua nilai $\mathrm{p}>0,05$ yakni $\mathrm{p}=0,128, \quad \mathrm{p}=0,102, \quad \mathrm{p}=0,227$ dan $\mathrm{p}=0,056$.

Uji korelasi bivariat koefisien pearson antara kelompok perlakuan Metilprednisolon ditambah dengan EEUBD dosis $100 \mathrm{mg} / \mathrm{KgBB}$ (K4) terhadap K1, K2, K3 dan K5. Rerata diameter germinal center pada $\mathrm{K} 4$ jika dibandingkan dengan masing-masing rerata diameter germinal center $\mathrm{K} 1$ didapatkan nilai $\mathrm{p}<0,05$ yakni $\mathrm{p}=0,049$ yang berarti terdapat perbedaan yang berbeda secara bermakna antara diameter germinal center pada K4 jika dibandingkan dengan masing-masing rerata diameter germinal center K1. Namun, jika diameter germinal center pada $\mathrm{K} 4$ jika dibandingkan dengan masing-masing rerata diameter germinal center $\mathrm{K} 2, \mathrm{~K} 4$ dan $\mathrm{K} 5$ didapatkan semua hasil yang berbeda secara tidak bermakna karena semua nilai $\mathrm{p}>0,05$ yakni $\mathrm{p}=0,850, \mathrm{p}=0,227$, dan $\mathrm{p}=0,157$.

Uji korelasi bivariat koefisien pearson antara kelompok perlakuan Metilprednisolon ditambah dengan EEUBD dosis $200 \mathrm{mg} / \mathrm{KgBB}$ (K5) terhadap K1, K2, K3 dan K4. Rerata diameter germinal center pada K5 jika dibandingkan dengan masing-masing rerata diameter germinal center $\mathrm{K} 1, \mathrm{~K} 2$, K3 dan $\mathrm{K} 4$ didapatkan semua hasil yang berbeda secara tidak bermakna karena semua nilai $p>0,05$ yakni $p=0,117, \quad p=0,323, \quad p=0,056 \quad$ dan $\mathrm{p}=0,157$.

Sehingga didapatkan perbandingan rerata diameter germinal center yang berbeda bermakna pada kelompok K1 (CMC Na ${ }^{+}$) dengan $\mathrm{K} 4$ berarti pada dosis EEUBD $100 \mathrm{mg} / \mathrm{KgBB}$ mampu merangsang pembentukan diameter germinal center mencapai nilai maksimal yang berarti terjadi proliferasi dan diferensiasi limfosit B secara maksimal pada dosis tersebut. Hal ini menunjukkan pada dosis tersebut EEUBD tidak hanya mampu mencegah terjadinya imunosupresi akibat pemberian metilprednisolon oral namun sekaligus mampu menjadi imunostimulator. Namun jika dosis ditingkatkan menjadi EEUBD 200mg/KgBB, ukuran diameter germinal center tidak meningkat jika dibandingkan dengan dosis EEUBD $100 \mathrm{mg} / \mathrm{KgBB}$. Hal ini berarti peningkatan kuantitas maksimal pada ukuran diameter germinal center terjadi pada dosis EEUBD $100 \mathrm{mg} / \mathrm{KgBB}$.

Peningkatan proliferasi dan diferensiasi limfosit B yang ditandai dengan peningkatan diameter germinal center dapat terjadi karena adanya kandunganPeningkatan aktivasi limfosit $\mathrm{B}$ yang ditandai dengan peningkatan kadar Ig G serum dapat terjadi karena adanya senyawa yang terdapat pada ekstrak etanol bawang dayak (falavonoid, fenolik, triperpenoid, tannin, alkaloid) mempunyai bioaktifitas sebagai imunostimulan agent (Febrinda, 2013; Wagner, 1985). Flavonol berpotensi sebagai imunostimulan karena mampu meningkatkan produksi IL-2 (interleukin-12) yang terlibat dalam aktivasi dan proliferasi sel T (Dewi et $a l, 2013)$. IL-12 akan menginduksi $\mathrm{T}$ helper (Th-0). Th-0 yang diinduksi oleh IL-12 akan mengalami proliferasi dan diferensiasi menjadi Th-1 dan Th-2. Selain mensekresi IL-12, APC juga mensekresi beberapa sitokin seperti IL-1. IL-1 kemudian menginduksi Th-1 untuk mensekresi IL-2 dan IFN- $\gamma$. Kedua sitokin ini kemudian menginduksi dan mengaktivasi Th-2 untuk mensekresi beberapa sitokin seperti IL4, IL-5 dan IL-6 dan IL-10 yang akan mengaktivasi sel limfosit $\mathrm{B}$ berprolifersi dan diferensiasi menjadi sel plasma yang dapat dilihat dengan peningkatan diameter germinal center. 
Kelenjar getah bening termasuk sistem limfoid perifer. Pada sistem limfoid perifer diferensiasi limfoid tergantung pada antigen (antigen dependent) (Abbas et al, 2014, Sudiana, 2011). Pada sistem limfoid perifer, baik limfosit $\mathrm{T}$ maupun limfosit $\mathrm{B}$ akan mengalami proliferasi dan diferensiasi bila terinduksi oleh suatu imunogen (Sudiana, 2011). Imunogen adalah sebuah substansi yang bila dimasukkan ke dalam tubuh mampu merangsang respon imun, baik respon selular maupun respon humoral atau keduanya (Kresno, 2010). Presentasi fragmen antigen/imunogen non-self diikuti oleh sekresi IL-12 dan IL-18 yang kemudian menstimulasi sel $\mathrm{T}$ menghasilkan interferon- $\gamma$ (INF- $\gamma$ ). Kehadiran INF- $\gamma$ akan mengakibatkan proliferasi sel B yang ada di germinal center (Campbell dalam Sulistiyana, 2015). Proliferasi sel B dapat ditunjukkan dengan peningkatan diameter germinal center (Bellanti dalam Sulistiyana, 2015).

Pengaruh Pemberian Ekstrak Etanol Umbi Bawang Dayak (EEUBD) Terhadap Pencegahan Penurunan Kadar IgG Serum

Tabel 3. Kadar Ig $\mathrm{G}$ serum mencit Balb/c antar kelompok perlakukan diukur menggunakan metode ELISA dengan panjang gelombang $450 \mathrm{~nm}$ dan $630 \mathrm{~nm}$ (satuan $\mathrm{ng} / \mathrm{ml}$ )

\begin{tabular}{|l|c|c|c|c|}
\hline \multicolumn{1}{|c|}{ Kelompok } & $\begin{array}{c}\text { Rera } \\
\text { ta }\end{array}$ & SD & $\begin{array}{c}\text { Mi } \\
\mathbf{n i} \\
\mathbf{m u} \\
\mathbf{m}\end{array}$ & $\begin{array}{c}\mathbf{M a} \\
\mathbf{k s i} \\
\mathbf{m u} \\
\mathbf{m}\end{array}$ \\
\hline $\mathrm{CMC} \mathrm{Na}^{+}$ & 39,4 & $\begin{array}{c}38, \\
8\end{array}$ & 1,9 & $\begin{array}{c}95, \\
6\end{array}$ \\
\hline $\mathrm{MP}$ & 50,3 & $\begin{array}{c}51, \\
0\end{array}$ & 8,2 & $\begin{array}{c}130 \\
, 8\end{array}$ \\
\hline $\begin{array}{l}\mathrm{MP}+\mathrm{EEUBD} \\
50 \mathrm{mg} / \mathrm{KgBB}\end{array}$ & 30,6 & $\begin{array}{c}48, \\
7\end{array}$ & 7,2 & $\begin{array}{c}130 \\
, 0\end{array}$ \\
\hline $\mathrm{MP}+\mathrm{EEUBD}$ & & 56, & & 132 \\
$100 \mathrm{mg} / \mathrm{KgBB}$ & 51,1 & 5 & 8,2 &, 4 \\
\hline $\mathrm{MP}+\mathrm{EEUBD}$ & & 65, & & 138 \\
$200 \mathrm{mg} / \mathrm{KgBB}$ & 70,3 & 8 & 7,7 &, 5 \\
\hline
\end{tabular}

Keterangan :

MP : Metilprednisolon

EEUBD : Ekstrak Etanol Umbi

Bawang Dayak

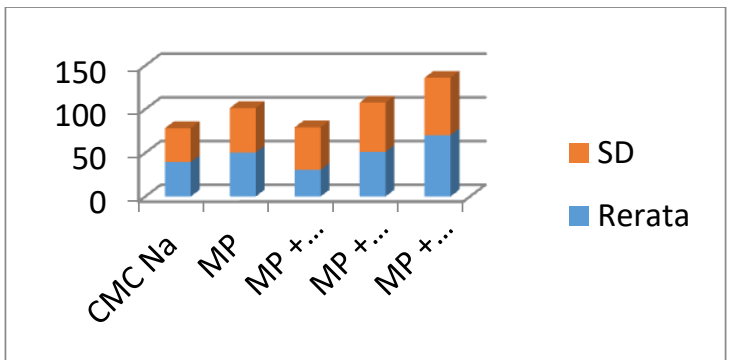

Gambar 3. Diagram batang rerata dan standar deviasi (SD) Imunoglobulin G (Ig G) pada serum darah mencit Balb/C

Tabel 4. Uji Korelasi Bivariat Koefisien Pearson rerata diameter germinal center

\begin{tabular}{|c|c|c|c|c|c|c|}
\hline & & $\begin{array}{c}\mathrm{CM} \\
\mathrm{C} \\
\mathrm{Na}\end{array}$ & MP & $\begin{array}{l}\mathrm{MP} \\
+ \\
\mathrm{EE} \\
\mathrm{UB} \\
\mathrm{D} \\
50 \\
\mathrm{mg} / \\
\mathrm{Kg} \\
\mathrm{BB}\end{array}$ & $\begin{array}{l}\mathrm{MP} \\
+ \\
\mathrm{EE} \\
\mathrm{UB} \\
\mathrm{D} \\
100 \\
\mathrm{mg} / \\
\mathrm{Kg} \\
\mathrm{BB}\end{array}$ & $\begin{array}{l}\text { MP } \\
+ \\
\text { EE } \\
\text { UB } \\
\text { D } \\
200 \\
\mathrm{mg} / \\
\mathrm{Kg} \\
\mathrm{BB}\end{array}$ \\
\hline $\mathrm{CMC}$ & Pearson & & - & - & & .92 \\
\hline \multirow[t]{4}{*}{$\mathrm{Na}$} & $\begin{array}{l}\text { Correlati } \\
\text { on }\end{array}$ & 1 & $\begin{array}{r}.32 \\
1\end{array}$ & $\begin{array}{r}.36 \\
6\end{array}$ & $\begin{array}{r}.22 \\
3\end{array}$ & $\begin{array}{r}8(* \\
*)\end{array}$ \\
\hline & Sig. (2- & & .53 & .47 & .67 & .00 \\
\hline & tailed) & . & 6 & 5 & 1 & 8 \\
\hline & $\mathrm{N}$ & 6 & 6 & 6 & 6 & 6 \\
\hline \multirow[t]{5}{*}{ MP } & Pearson & - & & 34 & - & - \\
\hline & Correlati & $\begin{array}{r}.32 \\
1\end{array}$ & 1 & $\begin{array}{r}.34 \\
0\end{array}$ & .64 & .04 \\
\hline & Sig. (2- & .53 & & .51 & .17 & .93 \\
\hline & tailed) & 6 & $\cdot$ & 0 & 0 & 3 \\
\hline & $\mathrm{N}$ & 6 & 6 & 6 & 6 & 6 \\
\hline \multirow{7}{*}{$\begin{array}{l}\mathrm{MP}+ \\
\mathrm{EEU} \\
\mathrm{BD} \\
50 \mathrm{mg} \\
/ \mathrm{KgB} \\
\mathrm{B}\end{array}$} & Pearson & & & & & \\
\hline & Correlati & - & & & - & - \\
\hline & & .36 & $\begin{array}{r}.34 \\
0\end{array}$ & 1 & .30 & .37 \\
\hline & & 6 & & & 4 & 7 \\
\hline & Sig. (2- & .47 & .51 & & .55 & .46 \\
\hline & tailed) & 5 & 0 & & 8 & 2 \\
\hline & $\mathbf{N}$ & 6 & 6 & 6 & 6 & 6 \\
\hline $\mathrm{MP}+$ & Pearson & & & & & \\
\hline EEU & Correlati & .22 & 64 & .30 & 1 & .03 \\
\hline $\begin{array}{l}\text { BD } \\
100 \mathrm{~m}\end{array}$ & on & 3 & 1 & 4 & & 2 \\
\hline
\end{tabular}




\begin{tabular}{|ll|r|r|r|r|r|}
$\mathrm{g} / \mathrm{Kg}$ & & & & & & \\
$\mathrm{BB}$ & & & & & & \\
& Sig. (2- & .67 & .17 & .55 & & .95 \\
& tailed) & 1 & 0 & 8 &. & 2 \\
$\mathrm{~N}$ & 6 & 6 & 6 & 6 & 6 \\
$\mathrm{MP}+$ Pearson & & & & & \\
$\mathrm{EEU}$ & Correlati & .92 & - & - & & \\
$\mathrm{BD}$ & on & $8(*$ & .04 & .37 & .03 & 1 \\
$200 \mathrm{~m}$ & & $*)$ & 4 & 7 & 2 & \\
$\mathrm{~g} / \mathrm{Kg}$ & & & & & & \\
$\mathrm{BB}$ & & & & & \\
& Sig. (2- & .00 & .93 & .46 & .95 & \\
& tailed) & 8 & 3 & 2 & 2 &. \\
& $\mathrm{~N}$ & 6 & 6 & 6 & 6 & 6 \\
\hline
\end{tabular}

** Correlation is significant at the 0.05 level (2-tailed).

Berdasarkan tabel 3. menunjukkan rerata kadar Ig $G$ serum paling tinggi pada kelompok K5 yang merupakan kelompok perlakuan dengan pemberian metilprednisolon oral dikombinasikan dengan EEUBD 200mg/KgBB.

Berdasarkan tabel 4. terlihat uji korelasi bivariat koefisien pearson antara kelompok perlakuan $\mathrm{CMC} \mathrm{Na}^{+}(\mathrm{K} 1)$ terhadap $\mathrm{K} 2, \mathrm{~K} 3, \mathrm{~K} 4$ dan K5. Jika dibandingkan kadar Ig $\mathrm{G}$ serum antara $\mathrm{K} 1$ dengan $\mathrm{K} 2$, $\mathrm{K} 3$ dan $\mathrm{K} 4$ didapatkan bahwa perbedaan rerata kadar Ig $\mathrm{G}$ serum berbeda tidak bermakna $(p>0,05)$ dengan nilai $\mathrm{p}$ masing-masing $0,536,0,475$ dan 0,671 . Sedangkan pada perbandingan rerata kadar Ig G serum antara K1 dengan K5 (kelompok perlakuan yang diberikan metilprednisolon dikombinasikan dengan EEUBD 200mg/KgBB) didapatkan hasil $\mathrm{p}<0,05$ yaitu $\mathrm{p}=0,008$.

Sedangkan uji korelasi bivariat koefisien pearson antara kelompok perlakuan Metilprednisolon (K2) terhadap K1, K3, K4 dan K5. Rerata kadar Ig G serum pada K2 jika dibandingkan dengan masing-masing rerata kadar Ig $\mathrm{G}$ serum $\mathrm{K} 1, \mathrm{~K} 3, \mathrm{~K} 4$ dan $\mathrm{K} 5$ didapatkan semua hasil yang berbeda secara tidak bermakna karena semua nilai $\mathrm{p}>0,05$ yakni $\mathrm{p}=0,536, \quad \mathrm{p}=0,510, \quad \mathrm{p}=0,170 \quad$ dan $\mathrm{p}=0,933$.

Uji korelasi bivariat koefisien pearson antara kelompok perlakuan Metilprednisolon ditambah dengan EEUBD dosis $50 \mathrm{mg} / \mathrm{KgBB}$ (K3) terhadap K1, K2, K4 dan K5. Rerata kadar Ig G serum pada K3 jika dibandingkan dengan masing-masing rerata kadar Ig $\mathrm{G}$ serum $\mathrm{K} 1, \mathrm{~K} 2, \mathrm{~K} 4$ dan $\mathrm{K} 5$ didapatkan semua hasil yang berbeda secara tidak bermakna karena semua nilai $\mathrm{p}>0,05$ yakni $\mathrm{p}=0,475$, $\mathrm{p}=0,510, \mathrm{p}=0,558$ dan $\mathrm{p}=0,462$.

Uji korelasi bivariat koefisien pearson antara kelompok perlakuan Metilprednisolon ditambah dengan EEUBD dosis $100 \mathrm{mg} / \mathrm{KgBB}$ (K3) terhadap K1, K2, K4 dan K5. Rerata kadar Ig $\mathrm{G}$ serum pada $\mathrm{K} 3$ jika dibandingkan dengan masing-masing rerata kadar Ig $G$ serum $\mathrm{K} 1, \mathrm{~K} 2, \mathrm{~K} 4$ dan $\mathrm{K} 5$ didapatkan semua hasil yang berbeda secara tidak bermakna karena semua nilai $p>0,05$ yakni $p=0,671$, $\mathrm{p}=0,170, \mathrm{p}=0,558$ dan $\mathrm{p}=0,952$.

Uji korelasi bivariat koefisien pearson antara kelompok perlakuan Metilprednisolon ditambah dengan EEUBD dosis $200 \mathrm{mg} / \mathrm{KgBB}$ (K5) terhadap K1, K2, K3 dan K4. Rerata kadar Ig G serum pada K4 jika dibandingkan dengan masing-masing rerata kadar Ig $\mathrm{G}$ serum K1 didapatkan nilai $\mathrm{p}<0,05$ yakni $\mathrm{p}=0,008$ yang berarti terdapat perbedaan yang berbeda secara bermakna antara kadar Ig G serum pada K5 jika dibandingkan dengan rerata kadar Ig G serum K1. Namun, jika kadar Ig G serum pada K5 jika dibandingkan dengan masing-masing rerata diameter germinal center $\mathrm{K} 2, \mathrm{~K} 3$ dan $\mathrm{K} 4$ didapatkan semua hasil yang berbeda secara tidak bermakna karena semua nilai $\mathrm{p}>0,05$ yakni $\mathrm{p}=0,933, \mathrm{p}=0,462$, dan $\mathrm{p}=0,952$.

Sehingga didapatkan perbandingan rerata kadar $\mathrm{Ig} G$ serum yang berbeda bermakna antara $\mathrm{K} 1\left(\mathrm{CMC} \mathrm{Na}^{+}\right)$dengan $\mathrm{K} 5$ (kelompok perlakuan yang diberikan metilprednisolon dikombinasikan dengan EEUBD 200mg/KgBB) didapatkan hasil $\mathrm{p}<0,05$ yaitu $\mathrm{p}=0,008$. Hal tersebut membuktikan pada dosis EEUBD $200 \mathrm{mg} / \mathrm{KgBB}$ mampu merangsang pembentukan $\mathrm{Ig} G$ serum mencapai nilai maksimal berarti pada dosis EEUBD $200 \mathrm{mg} / \mathrm{KgBB}$ mampu merangsang aktivasi limfosit B membentuk imunoglobulin G (Ig G) secara maksimal pada dosis tersebut. Hal ini menunjukkan pada dosis tersebut EEUBD tidak hanya mampu mencegah terjadinya imunosupresi akibat pemberian metilprednisolon oral namun sekaligus mampu menjadi imunomodulator yang meningkatkan produksi Ig $G$ serum mencit. Hal ini 
menunjukkan pada dosis tersebut terjadi peningkatan kualitas limfosit B.

Peningkatan aktivasi limfosit B yang ditandai dengan peningkatan kadar Ig G serum dapat terjadi karena adanya senyawa yang terdapat pada ekstrak etanol bawang dayak (falavonoid, fenolik, triperpenoid, tannin, alkaloid) mempunyai bioaktifitas sebagai imunostimulan agent (Febrinda, 2013; Wagner, 1985). Flavonol berpotensi sebagai imunostimulan karena mampu meningkatkan produksi IL-2 (interleukin-12) yang terlibat dalam aktivasi dan proliferasi sel $\mathrm{T}$ (Dewi et al, 2013). IL-12 akan menginduksi $\mathrm{T}$ helper (Th-0). Th-0 yang diinduksi oleh IL-12 akan mengalami proliferasi dan diferensiasi menjadi Th-1 dan Th-2. Selain mensekresi IL-12, APC juga mensekresi beberapa sitokin seperti IL-1. IL-1 kemudian menginduksi Th-1 untuk mensekresi IL-2 dan IFN- $\gamma$. Kedua sitokin ini kemudian menginduksi dan mengaktivasi Th-2 untuk mensekresi beberapa sitokin seperti IL4, IL-5 dan IL-6 dan IL-10 yang akan mengaktivasi sel limfosit $\mathrm{B}$ berdiferensiasi menjadi sel plasma (Sudiana, 2011). Pada respon awal (primer respons) antibodi yang terbentuk adalah kelas Ig $\mathrm{M}$. Ig $\mathrm{M}$ bisa berubah menjadi kelas imunoglobulin yang lain termasuk Ig G (switching). Perubahan Ig $M$ menjadi Ig $G$ sangat tergantung terhadap IFN- $\gamma$ sebagai sitokin yang dominan yang dapat memicu gen pengkode rantai $\mu$ (miu) pada limfosit B untuk mengalami switching sehingga yang dikode adalah rantai $\gamma$ (gamma) dan kemudian membentuk antibodi spesifik yaitu Ig G (Sudiana, 2011).

Pada penelitian ini peningkatan kadar Ig $G$ serum dapat terjadi oleh karena kandungan yang terdapat pada EEUBD mampu bersifat sebagai imunogen/imunostimulan sehingga terjadi respon imun yang bisa diamati dengan meningkatnya kadar Ig $G$ serum pada perlakuan dosis EEUBD 200mg/KgBB dikombinasikan dengan metilprednisolon (K5) jika dibandingkan dengan kadar Ig G serum kelompok kontrol yang hanya diberikan perlakuan $\mathrm{CMC} \mathrm{Na}^{+}(\mathrm{K} 1)$.

\section{DAFTAR PUSTAKA}

Abbas AK, Andrew H, and Pillai S. 2014. Cells and Tissues of The Immune. In Cellular and Molecular Immunology. $7^{\text {th }}$ Edition, Philadelphia; WB Elsevier Company, 15-34

Abbas AK, Andrew H, and Pillai S. 2014. Antibodies and Antigens. In Cellular and Molecular Immunology. $7^{\text {th }}$ Edition, Philadelphia; WB Elsevier Company, 89-105

Abbas AK, Andrew H, and Pillai S. 2014. Immunity to Microbes. In Cellular and Molecular Immunology. $7^{\text {th }}$ Edition, Philadelphia; WB Elsevier Company, 345-63

Annisa R. 2014. Uji Efek Imunomodulator Ekstrak Etanol Umbi Bawang Dayak (Eleutherine americana (Aubl) Merr) pada Mencit (Mus musculus). Makasar : Fakultas Kedokteran Universitas Hasanuddin. Retrieved : August 06, 2014, Available at : http://repository.unhas.ac.id:4001/dig ilib. Diakses tanggal 14 April 2015.

Azis, A. L. 2006. Penggunaan kortikosteroid di klinik ( The use of corticosteroid in clinics ). Divisi Gawat Darurat Lab/SMF Ilmu Kesehatan Anak FK Unair/RSUD dr Soetomo Surabaya. Available at http://old.pediatrik.com/buletin/2006 0220-uk51j3-buletin.pdf . Diakses tanggal 24 Agustus 2015

Baratawidjaja KG dan Rengganis I. 2010. Sistem Imun. Dalam Imunologi Dasar. Edisi ke-9, Jakarta; Fakultas Kedokteran Universitas Indonesia, 27-56

Baratawidjaja KG dan Rengganis I. 2010. Antigen dan Antibodi. Dalam Imunologi Dasar. Edisi ke-9, Jakarta; Fakultas Kedokteran Universitas Indonesia, 147-76 
Chairul dan Praptiwi, 2008. Uji Efektivitas Imunomodulator Tiga Jenis Zingiberaceae Secara In-Vitro Melalui Pengukuran Aktivitas Sel Makrofag Dan Kapasitas Fagositosis. Jakarta: Puslit Biologi LIPI, 1-7

Dewi L.K, Widyarti S, Rifai M, 2013. Pengaruh Pemberian Ekstrak Etanol Daun Sirsak (Annona muricata Linn.) terhadap Peningkatan Jumlah Sel T CD4+ dan CD8+ pada Timus Mencit (Mus musculus). Jurnal Biologi. Malang: Universitas Brawijaya, 1-5

Dexa Medica. Methylprednisolone. Available at : $\quad$ http://www.dexamedica.com/ourproduct/searchs/Methylprednisolone $\underline{\% 20}$. Diakses tanggal 29 Agustus 2015

Febrinda AE, Astawan M, Wresdiyati T, Yuliana ND. 2013. Kapasitas Antioksidan dan Inhibitor Alpha Glukosidase Ekstrak Umbi Bawang Dayak. Jurnal Teknologi dan Industri Pangan. 24 (2): 161-7

Febrinda AE et al. 2014. Hyperglycemic control and diabetes complication preventive activities of Bawang Dayak (Eleutherine palmifolic Merr.) bulbs extracts in allc 46 diabetic rats. International, Research Journal 21(4): 1405-1411. Available at / Journal homepage: http://www.ifrj.upm.edu.my. Diakses tanggal 25 Maret 2015

Firdaus T, 2014. Efektivitas Ekstrak Bawang Dayak (Eleutherine Palmifolia) Dalam Menghambat Pertumbuhan Bakteri Staphylococcus aureus. Skripsi. Universitas Islam Negeri Syarif Hidayatullah. Indonesia.

Galingging, R.Y. 2009. Bawang Dayak (Eleutherine palmifolia) Sebagai Tanaman Obat Multifungsi. Warta
Penelitian dan Pengembangan 15(3): 2-4.

Kresno, S.B. 2010. Imunologi : Diagnosis dan Prosedur Laboratorium. Edisi Kelima. Jakarta : Fakultas Kedokteran Indonesia, 64-65

Mata Kuliah Biologi, 2012. Respon Imun. Mata kuliah biologi. Available at : blogspot.com/2012/06/responimun.html Diakses pada tanggal 24 Agustus 2015.

Nur AM. 2011. Kapasitas Antioksidan Bawang Dayak (Eleutherine palmifolia) dalam Bentuk Segar, Simplisia dan Keripik, pada Pelarut Nonpolar, Semipolar dan Polar. Skripsi. Bogor : Fakultas Teknologi Pertanian Institut Pertanian Bogor, 176

BPOM. 2015. Glukokortikoid. Available at : http://pionas.pom.go.id/book/ionibab-6-sistem-endokrin-63kortikosteroid/632-glukokortikoid. Diakses pada tanggal 24 agustus 2015

Puspadewi R, Adirestuti P dan Menawati R. 2013. Khasiat Umbi Bawang Dayak (Eleutherine palmifolia (L.) Merr) sebagai Herbal Antimikroba Kulit. Kartika Jurnal Ilmiah Farmasi. 1(1):31-37

RSCM Kirana. 2014. Pemberian Kortikosteroid Dosis Tinggi dan/atau Obat Imunusupresif untuk Jangka Panjang. Available at : http://matafkui-rscm.org/panduanpasien/edukasi-pasien/penggunaankortikosteroid/. Diakses pada tanggal 24 agustus 2015 
Sudiana IK, 2005. Teknologi Ilmu Jaringan dan Imunohistokimia. Jakarta: Sagung Seto, 1-46

Sudiana IK, 2011. Limfosit dalam Patobiologi Molekuler Kanker. Jakarta: Salemba Medika, 77-83

Sulistyana MI. 2015. Pemanfaatan Polisakarida Krestin dari Coriolus versicolor sebagai Imunomodulator pada Mus musculus yang Terpapar Mycobacterium tuberculosis berdasarkan Indikator Konsentrasi IL-4 dan Histologi Limpa. Skripsi. Surabaya : Fakultas Sains dan Teknologi Universitas Airlangga, 174

Sunarjo. 2014. Bahan Kuliah Eksperimental Design. Dalam Mata Kuliah Metodologi Penelitian. Universitas Airlangga, 1-32

Sumarwoto T, 2004. Efek Pemberian Ekstrak Kedelai Dalam Menghambat Penurunan Kepadatan Tulang Pada Terapi Kortikosteroid Jangka Panjang Tikus Putih Jantan (Rattus norvegicus). Tesis. Universitas Airlangga. Indonesia, 1-83

Wagner H, 1985. Immunostimulants from medicinal plants. In Advances in Chinese medicinal materials research (Eds.) H.M. Chang; H.W. Yeung; W.W. Tso and A. Koo. World Scientific Publ. Co. Singapura : 159170.

Yanti F. 2014. Efek Penghambatan Siklus Sel dan Pemacuan Apoptosis Kombinasi Ekstrak Umbi Lapis Bawang Sabrang (Eleutherine bulbosa (Mill.) Urb.) dan Doksorubisin pada Sel Kanker Payudara. Tesis. Medan : Program Studi Magister Farmasi Universitas Sumatera Utara, 1-29
Yusni MA. 2008. Perbedaan Pengaruh Pemberian Fraksi Etanolik Bawang Dayak (Eleutherine palmifolia $L$. Merr) dengan 5-Fluorouracil terhadap Penghambatan Pertumbuhan Galur Sel Karsinoma Kolon HT29 dan Ekspresi p53 Mutan. Tesis. Fakultas Kedokteran Universitas Sebelas Maret/RSUD dr. Moewardi Surakarta, 1-79

Zalisar L. 2013 Flavonoid of Phyllanthus Niruri as Immunomodulator: A Prospect to Animal Disease Control. ARPN Journal of Science and Technology. 3(5): 529-30 